\title{
Local Actions for Reducing Global Greenhouse Gas Footprint: 10 Years of Covenant of Mayors Initiative
}

\author{
Luca Adami $^{1 *}$, Marco Tubino ${ }^{1}$, Marco Ragazzi $^{1}$, Fabio Conti $^{2}$, Elena Cristina Rada $^{2}$ \\ ${ }^{1}$ Department of Civil, Environmental and Mechanical Engineering, University of Trento, Trento 38123, Italy \\ ${ }^{2}$ University of Insubria, Department of Theoretical and Applied Sciences, Varese 21100, Italy
}

Corresponding Author Email: luca.adami@unitn.it

https://doi.org/10.18280/ijsdp.150216

Received: 14 May 2019

Accepted: 18 July 2019

\section{Keywords:}

Covenant of Mayors, climate change, energy efficiency, local energy plans, waste to energy

\begin{abstract}
Covenant of Mayor was launched in 2008 as a voluntary initiative for local administrations that intend to adopt a plan of interventions concerning greenhouse gas mitigations, achieving and exceeding the EU climate and energy targets. In its first decade of activity, Covenant of Mayors has become the world's largest initiative based on actions of energy saving and local climate mitigation, involving 250+ million inhabitants and 7700+ signatories in more than 50 countries worldwide, under the denomination of Global Covenant of Mayors for Climate and Energy. Globally, a total 5996 municipalities subscribed to the above-mentioned agreement in the first decade, in addition to 1743 progress plans and a wide database of indications regarding successful actions of Greenhouse Gas footprint mitigation at a European scale. This work reports on the global statistics of the initiative in the period 2008-2017 and the geographical location of the signatories within the territory of the European Union, highlighting limits and challenges of the initiative.
\end{abstract}

\section{INTRODUCTION}

Global climate is adapting to changes in ecosystems caused by mankind. If the impact of these changes could be considered almost negligible until the 18th century, starting from the industrial revolution, mankind has accelerated its development in all fields of society, thus affecting the basin of renewable and non-renewable resources present on the planet [1-4]. This suggests that strategies for sustainable management of resources that, in any case, are limited should focus on the maintenance of their resilience [5, 6].

Presently the Paris agreement on climate has been ratified by 185 countries [7] and represents the leading global framework on the topic. It aims [8-10] (i) to keep the global temperature rise in the XXI century below $2{ }^{\circ} \mathrm{C}$ above preindustrial levels, possibly limiting this increasing trend to $1.5^{\circ} \mathrm{C}$ and (ii) to strengthen the ability of countries to deal with the impacts of climate change.

The targets of the Paris agreement have been presented under several sub-targets, with different temporal horizons [11-13]. A first temporal target has been fixed, e.g. by European Community, in 2020 with the so called EU 20/20/20 package. The achievement of the 2020 targets has been monitored and presents various problems linked to aspects such as the uncertainty about the marginal costs of climate change [14].

Although the achievement of the objectives of the 20/20/20 package seems to be satisfied, the new long-term objectives set for 2050 present new challenges in crucial sectors for the development and sustenance of nations' populations, such as greenhouse gas (GHG) emissions due to e.g. breeding, transport, domestic heating and industry sectors [15-17].

For the mitigation of impacts in the various sectors described, the European Union has implemented measures aimed at encouraging green technologies instead of obsolete technologies. With the multiannual financial framework 20142020, the European Union has supported, through community co-financing channels, innovation paths concerning both research and development, and the realization of test projects and pilot projects specifically concerning also the topics of climate change and climate mitigation. From these points of view local authorities and municipalities represent the vanguard of the energy transition to sustainability and play a crucial role in mitigating the effects of climate change. Presently, the world's largest initiative for local climate and energy actions is the so called Covenant of Mayors (CoM) for Climate and Energy [18].

CoM started in 2008 with the aim to gather local governments to achieving the EU climate and energy targets. Municipalities or groups of them (called "signatories") can voluntarily adhere to CoM and sign a declaration stating that they plan to obtain specific targets of $\mathrm{CO}_{2}$ emissions reduction through specific local actions that are described in the Sustainable Energy Action Plan (SEAP) [19]. CoM initiative is part of the world climate change networks such as the Conference of Parties 21, "C40 cities", the ICLEI - Local Governments for Sustainability [20] and the Smart Cities Initiative [21].

To achieve the goal of reducing GHG emissions, crucial importance is exercised by the administrations that, alone or in small groups, decide to adopt a multi-year plan of actions to be implemented in the area of competence [15-17]. These actions include various sectors, such as: local electricity production, local heat and cold production, municipal buildings equipment facilities, public lighting, residential and tertiary buildings, transport [22]. 
In the transitory path towards a globally sustainable policy, waste can represent a resource to be valued energetically, especially in those emerging countries where growth in terms of population and production is rapid and only rarely is accompanied by energy development planning [23-27], or considered into the local actions of the CoM initiative due to the economic costs. The focus of the work is to provide a statistical analysis of the first 10 years of the CoM initiative and its status of implementation in terms of baseline of GHG footprint and mitigation actions.

\section{COVENANT OF MAYORS INITIATIVE}

$\mathrm{CoM}$ is the main European movement that involves local and regional authorities that voluntarily commit themselves to increase energy efficiency and the use of renewable energy sources in their territories. Through their commitment, the signatories of the Pact intend to reach and exceed the European target of $20 \%$ reduction of GHG emissions by 2020 .

Table 1. Signatories of SEAP-SECAP in the period 2008-2017 per different target (2020, adaptation, 2030) and percentage of municipalities and population involved

\begin{tabular}{|c|c|c|c|c|c|}
\hline Country & Target 2020 & Adapt. & Target 2030 & municipality \% & population \% \\
\hline Albania & 1 & 3 & 2 & $4.9 \%$ & $21.0 \%$ \\
\hline Algeria & 3 & 0 & 0 & $0.2 \%$ & $1.7 \%$ \\
\hline Armenia & 9 & 9 & 9 & $1.9 \%$ & $46.3 \%$ \\
\hline Austria & 12 & 2 & 2 & $0.6 \%$ & $22.8 \%$ \\
\hline Azerbaijan & 1 & 1 & 1 & $3.3 \%$ & $1.1 \%$ \\
\hline Belarus & 10 & 22 & 22 & $27.1 \%$ & $25.6 \%$ \\
\hline Belgium & 224 & 117 & 111 & $56.5 \%$ & $95.6 \%$ \\
\hline Bosnia-Herzegovina & 19 & 2 & 2 & $14.8 \%$ & $46.6 \%$ \\
\hline Bulgaria & 24 & 3 & 1 & $9.5 \%$ & $36.0 \%$ \\
\hline Croatia & 62 & 12 & 9 & $16.1 \%$ & $65.6 \%$ \\
\hline Cyprus & 24 & 0 & 0 & $77.4 \%$ & $41.3 \%$ \\
\hline Czechia & 6 & 5 & 4 & $0.2 \%$ & $19.9 \%$ \\
\hline Denmark & 37 & 6 & 1 & $37.8 \%$ & $56.6 \%$ \\
\hline Estonia & 5 & 1 & 0 & $2.2 \%$ & $41.6 \%$ \\
\hline Finland & 10 & 2 & 3 & $3.8 \%$ & $36.0 \%$ \\
\hline France & 81 & 14 & 12 & $0.2 \%$ & $24.4 \%$ \\
\hline Georgia & 11 & 5 & 5 & $23.9 \%$ & $48.4 \%$ \\
\hline Germany & 58 & 19 & 8 & $0.6 \%$ & $22.7 \%$ \\
\hline Greece & 121 & 50 & 39 & $47.5 \%$ & $51.3 \%$ \\
\hline Hungary & 30 & 11 & 10 & $1.2 \%$ & $39.2 \%$ \\
\hline Iceland & 1 & 1 & 1 & $1.3 \%$ & $35.9 \%$ \\
\hline Ireland & 8 & 7 & 6 & $37.5 \%$ & $53.7 \%$ \\
\hline Israel & 3 & 0 & 0 & $5.9 \%$ & $1.9 \%$ \\
\hline Italy & 3187 & 212 & 152 & $41.5 \%$ & $68.9 \%$ \\
\hline Jordan & 1 & 1 & 1 & $16.7 \%$ & $2.9 \%$ \\
\hline Kazakhstan & 1 & 0 & 0 & & $12.8 \%$ \\
\hline Latvia & 19 & 3 & 2 & $17.8 \%$ & $58.4 \%$ \\
\hline Lebanon & 3 & 7 & 7 & $34.6 \%$ & $3.0 \%$ \\
\hline Lithuania & 14 & 1 & 1 & $25.0 \%$ & $46.7 \%$ \\
\hline Luxemburg & 2 & 0 & 0 & $1.9 \%$ & $4.4 \%$ \\
\hline Macedonia & 1 & 0 & 0 & $1.2 \%$ & $28.5 \%$ \\
\hline Malta & 24 & 0 & 0 & $35.3 \%$ & $26.6 \%$ \\
\hline Moldova & 12 & 8 & 8 & $4.6 \%$ & $13.5 \%$ \\
\hline Montenegro & 3 & 0 & 0 & $13.6 \%$ & $22.8 \%$ \\
\hline Morocco & 5 & 6 & 6 & & $6.5 \%$ \\
\hline Netherlands & 18 & 5 & 3 & $5.4 \%$ & $25.0 \%$ \\
\hline Norway & 8 & 0 & 0 & $1.9 \%$ & $26.9 \%$ \\
\hline Palestine & 4 & 1 & 1 & & $4.0 \%$ \\
\hline Poland & 38 & 2 & 2 & $1.6 \%$ & $11.4 \%$ \\
\hline Portugal & 113 & 23 & 9 & $38.6 \%$ & $57.5 \%$ \\
\hline Romania & 61 & 16 & 15 & $2.3 \%$ & $23.1 \%$ \\
\hline Serbia & 1 & 0 & 0 & $0.6 \%$ & $2.7 \%$ \\
\hline Slovakia & 4 & 10 & 9 & $0.4 \%$ & $14.3 \%$ \\
\hline Slovenia & 29 & 2 & 1 & $13.7 \%$ & $34.3 \%$ \\
\hline Spain & 1534 & 329 & 311 & $18.9 \%$ & $54.8 \%$ \\
\hline Sweden & 52 & 8 & 8 & $19.3 \%$ & $46.0 \%$ \\
\hline Switzerland & 9 & 0 & 0 & $0.4 \%$ & $10.2 \%$ \\
\hline Tajikistan & 1 & 0 & 0 & $1.7 \%$ & $0.4 \%$ \\
\hline Tunisia & 1 & 1 & 1 & $0.6 \%$ & $3.0 \%$ \\
\hline Turkey & 10 & 5 & 4 & $0.4 \%$ & $17.7 \%$ \\
\hline Ukraine & 81 & 92 & 92 & $33.5 \%$ & $33.4 \%$ \\
\hline United Kingdom & 34 & 7 & 2 & & $32.8 \%$ \\
\hline TOTAL & 5996 & 1024 & 881 & $5.0 \%$ & $24.8 \%$ \\
\hline
\end{tabular}




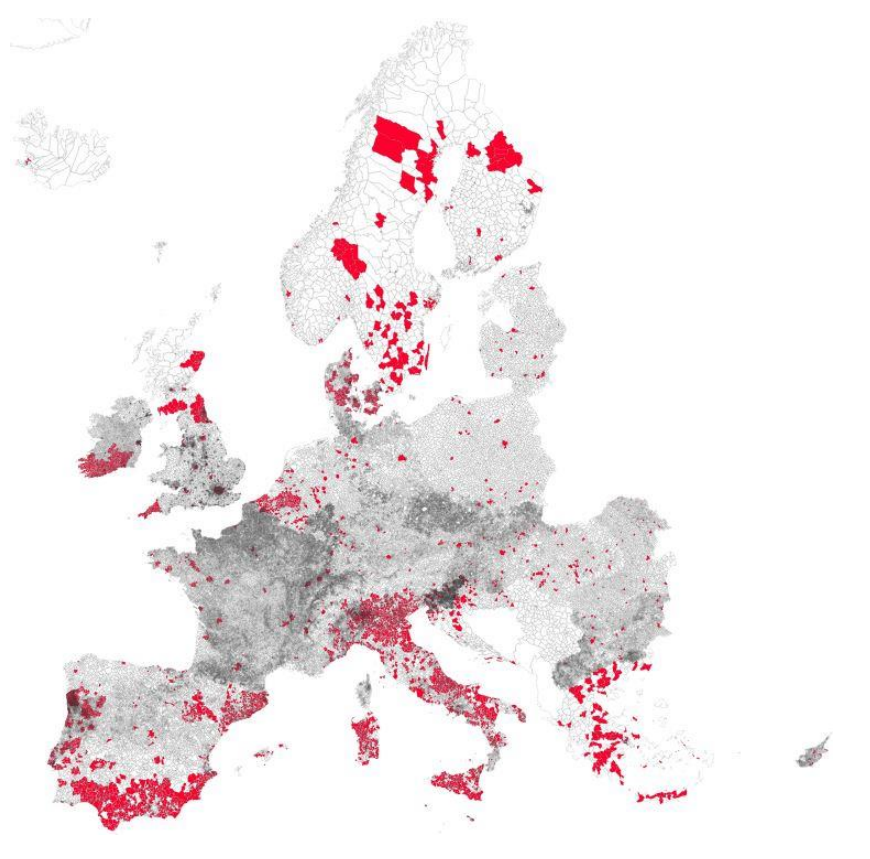

Figure 1. Signatories of SEAP-SECAP in the period 20082017, with 2020 target. Background grey lines represent borders of local municipalities

After the adoption of the European Climate and Energy Package in 2008, the European Commission launched the CoM to endorse and support the efforts made by local authorities in achieving European targets. Due to its unique characteristics - being the only movement of this kind to mobilize local and regional actors for the pursuit of the objectives of the European Union - the CoM is considered by the European institutions as an exceptional model of multilevel governance.

Signatories are committed to a series of steps and agree to present reports and be monitored on their actions. By the established deadlines, they formally undertake (i) to develop adequate administrative structures, including the allocation of sufficient human resources, in order to take the necessary actions, (ii) to prepare the Baseline Emission Inventory (BEI) that represents the emission condition at the date of the signature of the plan, (iii) to prepare a Sustainable Energy and Action Plan (SEAP) that includes concrete measures to achieve the minimum target of $20 \%$ in terms of reducing $\mathrm{CO}_{2}$ emissions by 2020, (iv) to submit progress plans at least every two years from the date of presentation of the SEAP for evaluation, monitoring and verification purposes, including the so called Monitoring Emission Inventory (MEI) for a direct comparison with the BEI.

Several recent studies on the topic of the CoM initiative have been published, analysing CoM initiative at different scales, from national [19, 28], to regional [29-34] and local [35-38], including also trans-national comparisons [39-44]. Results of the progress plans can be compared with different GHG emissions balances [45], in order to evaluate the progress of local plans [46-48], especially in urban contexts [49-50].

Single and small groups of municipalities play a leading role in the application of the SEAPs [51-53] and their economic investments are supported by citizens [54-55] even if issues and barriers are still remaining [56].

In the first decade of activity (2008-2017) CoM initiative has been joined by a total of 5996 signatories with 2020 target, 1024 with adaptation, 881 with 2030 targets.
By updating and extending data shown by Kona et al. [48], in Table 1 we present the list of countries with at least one signatory for one of the three targets proposed by the initiative. Table 1 includes 52 countries, geographically located in the European and Mediterranean area. Italy and Spain are the only two countries with $1000+$ signatories for 2020 targets, but national distribution in the single country is different. As presented in Figure 1, Spain shows a greater density of signatories in the coastal area of the south, in Catalonia and Aragon regions, while other regions as Galicia, Castilla and Leon are almost not represented.

On the contrary, Italy shows a rather homogeneous distribution of signatories in the country, with all the regions with at least one signatory and peaks of more than $90 \%$ of municipalities that signed the agreement in regions like Marche.

Only two countries (Belgium and Cyprus) has more than $50 \%$ of the municipalities that published a SEAP, while in terms of percentage of population involved in the initiative on the total of the country, presently 9 countries satisfied this criterion: Belgium (95.6\%), Italy (68.9\%), Croatia (65.6\%), Latvia (58.4\%), Portugal (57.5), Denmark (56.6\%), Spain $(58.4 \%)$, Ireland (53.7\%), Greece (51.3\%).

Countries like France and Germany, Montenegro, Norway have only a few dozen signatories, while still reaching a percentage of population involved larger than $22 \%$ of the total, indicating that cities and metropolis are easier to participate than small cities and villages.

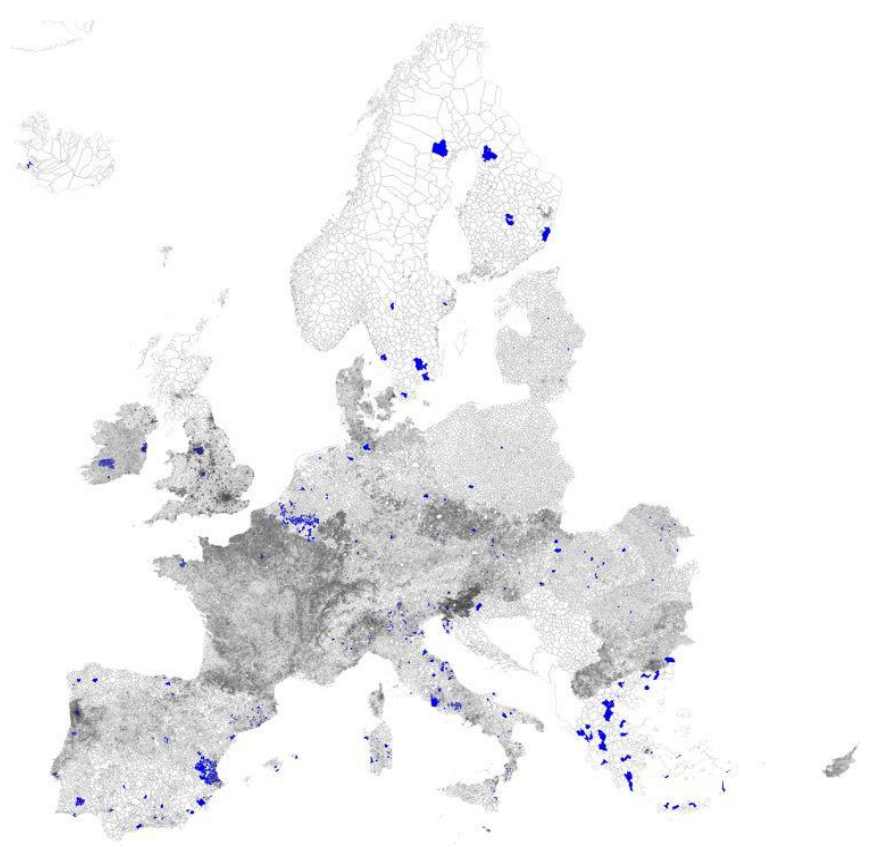

Figure 2. Signatories of SEAP-SECAP in the period 20082017, with 2030 target. Background grey lines represent borders of local municipalities

In Figure 2 the geographical distribution of the signatories of the CoM initiative with 2030 target in the EU region is presented. In this case only 881 signatories are present in the whole region, but the signatories that are committed to the 2030 targets have exceeded the 2020 target signatories already since 2016.

Progress plans cover up to seven sectors in which specific actions are identified: industry, local electricity production, local heat cold production, municipal buildings equipment 
facilities, public lighting, residential buildings, tertiary buildings, transport; an eighth sector, called others, includes the remaining local fonts of energy consumption. From a total of 1743 progress plans, presently we have the following total per sector:

- Industry

- Local electricity production

- Local heat cold production

- Municipal buildings equipment facilities 1063

- Public lighting 849

- Residential buildings 505

- Tertiary buildings equipment facilities 552

- Transport

- Others

These data show that, on average, each progress plan contains between two and three sectors of action (average $=$ 2.81) and that the two sectors specifically related to public administration (Municipal buildings equipment facilities and public lighting) covers together 1528 progress plans on a total of $1743(87.7 \%)$. In this area the most common actions to reduce the dependency of municipalities from non-renewable sources of energy regard waste to energy (WtE) (77 actions) in particular in the breeding sector, while the industrial sector is still marginal, and different national legislations and limits to emissions are generating difficulties in the application of existing and innovative technologies.

\section{DISCUSSION AND CONCLUSIONS}

In this work we presented a global statistics of CoM signatories in the first decade of activity of the initiative (20082017), describing the SEAPs subscribed in terms of target (2020, adaptation, 2030) and of municipalities and population involved. Progress plans, that are still

less than $30 \%$ of the active SEAPs, describe the relative success of the initiative in terms of GHG emission reduction and of population involved. Despite the EU encourages climate actions with local emphasis (e.g. through calls for actions co-financed by EU itself), the rate of success of the initiative can be increased, for example, through a coordination of the initiative of rural municipalities (e.g. with less than 5000 inhabitants), in which often the limited presence of technical and administrative staff can influence the progress of the SEAPs. Moreover, a limited 'network-effect' between municipalities or a coordination of the initiative at intermediate scale (e.g. provincial and regional) is presently limiting a possible virtuous circle that could generate a scale effect for smaller administrations with fewer technical and economic resources.

\section{ACKNOWLEDGEMENTS}

Thanks are due to the Municipality of Oppeano (Italy) for its financial support and to Giacomo Castagna for the technical support in the creation of the GIS-based database.

\section{REFERENCES}

[1] Walther, G., Post, E., Convey, P., Menzel, A., Parmesan, C., Beebee, T.J.C., Fromentin, J., Hoegh-Guldberg, O.,
Bairlein, F. (2002). Ecological responses to recent climate change. Nature, 416(6879): 389-395. https://doi.org/10.1038/416389a

[2] Parmesan, C., Yohe, G. (2002). A globally coherent fingerprint of climate change impacts across natural systems. Nature, 421(6918): 37-42. https://doi.org/10.1038/nature01286

[3] Shindell, D., Kuylenstierna, J.C.I., Vignati, E., Van Dingenen, R., Amann, M., Klimont, Z., Anenberg, S.C., Muller, N., Janssens-Maenhout, G., Raes, F., Schwartz, J., Faluvegi, G., Pozzoli, L., Kupiainen, K., HöglundIsaksson, L., Emberson, L., Streets, D., Ramanathan, V., Hicks, K., Oanh, N.T.K., Milly, G., Williams, M., Demkine, V., Fowler, D. (2012). Simultaneously mitigating near-term climate change and improving human health and food security. Science, 335(6065): 183-189. https://doi.org/10.1126/science. 1210026

[4] Sala, O.E., Chapin III, F.S., Armesto, J.J., Berlow, E., Bloomfield, J., Dirzo, R., Huber-Sanwald, E., Huenneke, L.F., Jackson, R.B., Kinzig, A., Leemans, R., Lodge, D.M., Mooney, H.A., Oesterheld, M., Poff, N.L., Sykes, M.T., Walker, B.H., Walker, M., Wall, D.H. (2000). Global biodiversity scenarios for the year 2100 . Science, 287(5459):

1770-1774. https://doi.org/10.1126/science.287.5459.1770

[5] Scheffer, M., Carpenter, S., Foley, J.A., Folke, C., Walker, B. (2001). Catastrophic shifts in ecosystems. Nature, $\quad 413(6856)$ : 591-596. https://doi.org/10.1038/35098000

[6] Pecl, G.T., Araújo, M.B., Bell, J.D., Blanchard, J., Bonebrake, T.C., Chen, I.C., Clark, T.D., Colwell, R.K., Danielsen, F., Evengård, B., Falconi, L., Ferrier, S., Frusher, S., Garcia, R.A., Griffis, R.B., Hobday, A.J., Janion-Scheepers, C., Jarzyna, M.A., Jennings, S., Lenoir, J., Linnetved, H.I., Martin, V.Y., McCormack, P.C., McDonald, J., Mitchell, N.J., Mustonen, T., Pandolfi, J.M., Pettorelli, N., Popova, E., Robinson, S.A., Scheffers, B.R., Shaw, J.D., Sorte, C.J.B., Strugnell, J.M., Sunday, J.M., Tuanmu, M.N., Vergés, A., Villanueva, C., Wernberg, T., Wapstra, E., Williams, S.E. (2017) Biodiversity redistribution under climate change: Impacts on ecosystems and human well-being. Science, 355(6332). https://doi.org/10.1126/science.aai9214

[7] United Nations - Climate Change, Paris Agreement Status of Ratification. website: https:/unfccc.int/process/the-paris-agreement/status-ofratification. Last accessed: 02 April 2019.

[8] Rogelj, J., Den Elzen, M., Höhne, N., Fransen, T., Fekete, H., Winkler, H., Schaeffer, R., Sha, F., Riahi, K. And Meinshausen, M. (2016). Paris Agreement climate proposals need a boost to keep warming well below $2 \mathrm{C}$. Nature, 534(7609): 631-639. https://doi.org/10.1038/nature18307

[9] Schleussner, C.F., Lissner, T.K., Fischer, E.M., Wohland, J., Perrette, M., Golly, A., Rogelj, J., Childers, K., Schewe, J., Frieler, K., Mengel, M., Hare, W., Schaeffer, M. (2016). Differential climate impacts for policyrelevant limits to global warming: The case of $1.5^{\circ} \mathrm{C}$ and 2 C. Earth System Dynamics, 7(2): 327-351. https://doi.org/10.5194/esd-7-327-2016

[10] Schleussner, C., Rogelj, J., Schaeffer, M., Lissner, T., Licker, R., Fischer, E.M., Knutti, R., Levermann, A., Frieler, K., Hare, W. (2016). Science and policy characteristics of the Paris Agreement temperature goal. 
Nature Climate Change, 6(9): 827-835 https://doi.org/10.1038/nclimate3096

[11] European Commission - Climate change, 2020 climate \& energy package. website: https://ec.europa.eu/clima/policies/strategies/2020_en. Last accessed: 02 April 2019.

[12] European Commission - Climate change, 2030 climate \& energy framework. website: https://ec.europa.eu/clima/policies/strategies/2030_en. Last accessed: 02 April 2019.

[13] European Commission - Climate change, 2050 longterm strategy. website: https://ec.europa.eu/clima/policies/strategies/2050_en. Last accessed: 02 April 2019.

[14] Tol, R.S.J. (2012). A cost-benefit analysis of the EU 20/20/2020 package. Energy Policy, 49: 288-295. https://doi.org/10.1016/j.enpol.2012.06.018

[15] Berners-Lee, M., Howard, D.C., Moss, J., Kaivanto, K., Scott, W.A. (2011). Greenhouse gas footprinting for small businesses - The use of input-output data. Science of the Total Environment, 409(5): 883-891. https://doi.org/10.1016/j.scitotenv.2010.11.023

[16] Larsen, H.N., Hertwich, E.G. (2009). The case for consumption-based accounting of greenhouse gas emissions to promote local climate action. Environmental Science and Policy, 12(7): 791-798. https://doi.org/10.1016/j.envsci.2009.07.010

[17] West, J.J., Smith, S.J., Silva, R.A., Naik, V., Zhang, Y., Adelman, Z., Fry, M.M., Anenberg, S., Horowitz, L.W., Lamarque, J. (2013). Co-benefits of mitigating global greenhouse gas emissions for future air quality and human health. Nature Climate Change, 3(10), 885-889. https://doi.org/10.1038/nclimate2009

[18] Pablo-Romero, M.P., Sánchez-Braza, A., Manuel González-Limón, J. (2015). Covenant of Mayors: Reasons for Being an Environmentally and Energy Friendly Municipality. Review of Policy Research, 32(5): 576-599. https://doi.org/10.1111/ropr.12135

[19] Coelho, S., Russo, M., Oliveira, R., Monteiro, A., Lopes, M., Borrego, C. (2018). Sustainable energy action plans at city level: A Portuguese experience and perception. Journal of Cleaner Production, 176: 1223-1230. https://doi.org/10.1016/j.jclepro.2017.11.247

[20] ICLEI - Local Governments for Sustainability, Local Solutions to Global Challenges, ICLEI Bonn Center, Bonn. Online: http://archive.iclei.org/fileadmin/user_upload/document s/Global/About_ICLEI/brochures/ICLEI-intro-2009.pdf, 2010. Last accessed: 02 April 2019.

[21] European Commission. In: Investing in the Development of Low Carbon Technologies (SET-plan) Communication from the commission to the European Parliament, the Council, the European Economic and Social Committee and the Committee of the Regions, COM (2014), vol. 15. European Commission, Brussels, 2009.

[22] Adami, L., Castagna, G., Ragazzi, M., Tubino, M. (2018). Covenant of Mayors committed to local sustainable energy: The Italian case. Energy Production and Management in the 21st Century III: The Quest for Sustainable Energy (WIT Transactions on Ecology and the Environment), 222: 35-46. https://doi.org/10.2495/EQ180041

[23] Adami, L., Castagna, G., Magaril, E., Giurea, R.,
Ferronato, N., Ruggieri, G., Torretta, V., Rada, E.C. (2018). Criticalities and potentialities of local renewable sources of energy. Energy Production and Management in the 21st Century III: The Quest for Sustainable Energy (WIT Transactions on Ecology and the Environment), 222: 103-115. https://doi.org/10.2495/EQ180101

[24] Cheng, H., Hu, Y. (2010). Municipal solid waste (MSW) as a renewable source of energy: Current and future practices in China. Bioresource Technology, 101(11): 3816-3824.

https://doi.org/10.1016/j.biortech.2010.01.040

[25] Fargione, J., Hill, J., Tilman, D., Polasky, S., Hawthorne, P. (2008). Land clearing and the biofuel carbon debt. Science, 319(5867): 1235-1238. https://doi.org/10.1126/science. 1152747

[26] Rada, E.C., Ragazzi, M., Torretta, V., Castagna, G., Adami, L., Cioca, L.I. (2018). Circular economy and waste to energy. AIP Conference Proceedings, 1968(030050).

[27] Rada, E.C., Castagna, G., Adami, L., Torretta, V., Ragazzi, M. (2018). Compensation opportunities and waste-to-energy plants. AIP Conference Proceedings, 1968(030065).

[28] Batas Bjelic, I., Ciric, R.M. (2014). Optimal distributed generation planning at a local level - A review of Serbian renewable energy development. Renewable and Sustainable Energy Reviews, 39: 79-86. https://doi.org/10.1016/j.rser.2014.07.088

[29] Oliver-Solà, J., Armero, M., De Foix, B.M., Rieradevall, J. (2013). Energy and environmental evaluation of municipal facilities: Case study in the province of Barcelona. Energy Policy, 61: 920-930. https://doi.org/10.1016/j.enpol.2013.06.053

[30] Famoso, F., Lanzafame, R., Monforte, P., Scandura, P.F. (2015). Analysis of the Covenant of Mayors initiative in Sicily. Energy Procedia, 82: 482-492. https://doi.org/10.1016/j.egypro.2015.12.122

[31] Mahbub, M.S., Viesi, D., Crema, L. (2016). Designing optimized energy scenarios for an Italian Alpine valley: the case of Giudicarie Esteriori. Energy, 116: 236-249. https://doi.org/10.1016/j.energy.2016.09.090

[32] Matak, N., Krajačić, G., Pilato, A.M. (2016). Integrating sustainable energy action plans for island municipalities: Case study of Korcula. Thermal Science, 20(4): 10371048. https://doi.org/10.2298/TSCI151127109M

[33] Pablo-Romero, M.D.P., Pozo-Barajas, R., SánchezBraza, A. (2016). Analyzing the effects of Energy Action Plans on electricity consumption in Covenant of Mayors signatory municipalities in Andalusia. Energy Policy, 99: 12-26. https://doi.org/10.1016/j.enpol.2016.09.049

[34] Roca, A.V. (2017). The promotion of photovoltaic for self-consumption in the local public administration: The case of the Barcelona Provincial Council. Revista de Obras Publicas, 164(3584): 86-91.

[35] Lombardi, M., Rana, R., Pazienza, P., Tricase, C. (2014). The European policy for the sustainability of urban areas and the covenant of mayors' initiative: A case study. Pathways to Environmental Sustainability: Methodologies and Experiences, Springer-Verlag: Berlin and NY, 18: 183-192. https://doi.org/10.1007/978-3319-03826-1 18

[36] Schenone, C., Delponte, I., Pittaluga, I. (2015). The preparation of the Sustainable Energy Action Plan as a city-level tool for sustainability: The case of Genoa. 
Journal of Renewable and Sustainable Energy, 7(3): 033126. https://doi.org/10.1063/1.4921723

[37] Nuss-Girona, S., Llausàs, A., Figueras, J., Morera, S. (2016). The SEAP in the city of Girona, a crossroads between boldness and pragmatism. Local Environment, 21(4): 476-503. https://doi.org/10.1080/13549839.2014.974150

[38] Scorza, F., Santopietro, L., Giuzio, B., Amato, F., Murgante, B., Casas, G.L. (2017). Conflicts between environmental protection and energy regeneration of the historic heritage in the case of the city of Matera: Tools for assessing and dimensioning of sustainable energy action plans (SEAP). Lecture Notes in Computer Science. In: Computational Science and Its Applications - ICCSA 2017. 10409, 37: 527-539. https://doi.org/10.1007/9783-319-62407-5 37

[39] Amorim, E.V. (2014). Sustainable energy action plans: project management intercomparison. Procedia Technologies, $\quad 16: \quad 1183-1189$ https://doi.org/10.1016/j.protcy.2014.10.133

[40] Croci, E., Lucchitta, B., Janssens-Maenhout, G., Martelli, S., Molteni, T. (2017). Urban $\mathrm{CO}_{2}$ mitigation strategies under the Covenant of Mayors: An assessment of 124 European cities. Journal of Cleaner Production, 169: 161-177. https://doi.org/10.1016/j.jclepro.2017.05.165

[41] Haupt W. (2018). European Municipalities Engaging in Climate Change Mitigation and Adaptation Networks: Examining the Case of the Covenant of Mayors. In: Yamagata Y., Sharifi A. (eds) Resilience-Oriented Urban Planning. Lecture Notes in Energy, Springer International Publishing, Cham, 65: 93-110. https://doi.org/10.1007/978-3-319-75798-8 5

[42] Kulozu Uzunboy, N. (2019). Effect of transnational climate networks on climate experiments: The Nilüfer Municipality, a case from Turkey. Environment, Development and Sustainability, 1387585X https://doi.org/10.1007/s10668-019-00332-5

[43] Pasimeni, M.R., Valente, D., Zurlini, G., Petrosillo, I. (2019). The interplay between urban mitigation and adaptation strategies to face climate change in two European countries. Environmental Science and Policy, 95: 20-27. https://doi.org/10.1016/j.envsci.2019.02.002

[44] Pietrapertosa, F., Khokhlov, V., Salvia, M., Cosmi, C. (2018). Climate change adaptation policies and plans: A survey in 11 South East European countries. Renewable and Sustainable Energy Reviews, 81: 3041-3050. https://doi.org/10.1016/j.rser.2017.06.116

[45] Cellura, M., Cusenza, M.A., Longo, S. (2018). Energyrelated GHG emissions balances: IPCC versus LCA. Science of the Total Environment, 628-629: 1328-1339. https://doi.org/10.1016/j.scitotenv.2018.02.145

[46] Aguiar, F.C., Bentz, J., Silva, J.M.N., Fonseca, A.L., Swart, R., Santos, F.D., Penha-Lopes, G. (2018). Adaptation to climate change at local level in Europe: An overview. Environmental Science and Policy, 86: 38-63. https://doi.org/10.1016/j.envsci.2018.04.010

[47] Ringel, M. (2018). Tele-coupling energy efficiency polices in Europe: Showcasing the German governance arrangements. Sustainability (Switzerland), 10(6): 1754. https://doi.org/10.3390/su10061754

[48] Kona, A., Bertoldi, P., Monforti-Ferrario, F., Rivas, S., Dallemand, J.F. (2018). Covenant of Mayors signatories leading the way towards 1.5 degrees global warming pathway. Sustainable Cities and Society, 41: 568-575. https://doi.org/10.1016/j.scs.2018.05.017

[49] Kern, K. (2019). Cities as leaders in EU multilevel climate governance: Embedded upscaling of local experiments in Europe. Environmental Politics, 28(1): 125-145. https://doi.org/10.1080/09644016.2019.1521979

[50] Monforti-Ferrario, F., Kona, A., Peduzzi, E., Pernigotti, D., Pisoni, E. (2018). The impact on air quality of energy saving measures in the major cities signatories of the Covenant of Mayors initiative. Environment international, 118: 222-234. https://doi.org/10.1016/j.envint.2018.06.001

[51] Lee, T. (2018). Local energy agencies and cities' participation in translocal climate governance. Environmental Policy and Governance, 28(3): 131-140. https://doi.org/10.1002/eet.1798

[52] Melica, G., Bertoldi, P., Kona, A., Iancu, A., Rivas, S., Zancanella, P. (2018). Multilevel governance of sustainable energy policies: The role of regions and provinces to support the participation of small local authorities in the Covenant of Mayors. Sustainable Cities and Society, 39: 729-739. https://doi.org/10.1016/j.scs.2018.01.013

[53] Pablo-Romero, M.D.P., Pozo-Barajas, R., SánchezBraza, A. (2018). Analyzing the effects of the benchmark local initiatives of Covenant of Mayors signatories. Journal of Cleaner Production, 176: 159-174. https://doi.org/10.1016/j.jclepro.2017.12.124

[54] Pablo-Romero, M.P., Sánchez-Braza, A., Manuel González-Limón, J. (2015). Covenant of Mayors: Reasons for Being an Environmentally and Energy Friendly Municipality. Review of Policy Research, 32(5): 576-599. https://doi.org/10.1111/ropr.12135

[55] Martelli, S., Janssens-Maenhout, G., Paruolo, P., Bréchet, T., Strobl, E., Guizzardi, D., Cerutti, A.K., Iancu, A. (2018). Do Voters Support Local Commitments for Climate Change Mitigation in Italy? Ecological Economics, 144: 27-35. https://doi.org/10.1016/j.ecolecon.2017.06.035

[56] Christoforidis, G.C., Chatzisavvas, K.C., Lazarou, S., Parisses, C. (2013). Covenant of Mayors initiative. Public perception issues and barriers in Greece. Energy Policy, 60: 643-655. 